\title{
Sexual behaviour and fertility in Icelandhorse herds
}

\author{
B. Steinbjörnsson ${ }^{1}$ and H. Kristjansson²
}

${ }^{1}$ Klinik für Pferde, Tierärztliche Hochschule Hannover, Germany; ${ }^{2}$ Isteka-Icelandic Pharmaceuticals Ltd, Reykjavik, Iceland

\begin{abstract}
Summary
During recent years horsebreeders in Iceland observed decreasing fertility of their mares. In order to gain knowledge about factors influencing fertility of Icelandhorses on pasture several aspects were monitored.

In the years 1996-1998 close to 100 breeding herds comprising over 2000 mares (from 9 to 39 per herd) with one stallion per herd (age from 2 to 26 years) were monitored repeatedly for 8-9 weeks, starting at least 50 days after the stallion joined the mares. Monitoring comprised weekly serum sampling and determination of pregnancy by means of measuring equine choriogonadotropin (eCG) levels by enzyme linked immunosorbent assay (ELISA). An overall pregnancy rate of $76 \%$ was found provided the stallion was allowed to serve the mares for at least 10 weeks.

Two other herds were monitored more closely by observing them for one and two heat periods continuously for 24h per day (made possible by sufficiently lucid Icelandic summer nights) by placing a camper in the middle of the pasture and by unequivocal marking of each horse. Some of the mares received clinical, gynaecological, and ultrasonic investigation in order to determine precisely the beginning of their heat and their date of ovulation. Herd A comprised 23 fertile mares plus an 9 years old stallion. Herd B was made up of 10 fertile cycling mares plus 3 years old stallion. These herds received continuous observation for 42 and 28 days, respectively. The stallions served each mare of their herd with 6.0 and 5.7 mounting per heat which lasted in average 4.4 and 4.7 days, respectively. The result of their matings were determined by the subsequent foaling rates of $87 \%$ and $90 \%$ respectively.

These foaling rates were clearly above the average pregnancy rate determined in the overall eCG-study. Of major influence on the remarkably different mating success (between $36 \%$ and $96 \%$ ) among the herds studied was the mare to stallion ratio per heat period. The age of the stallion and a composition of the mares in the herds is of great importance too. In order to obtain optimal foaling rates with Icelandhorses on pasture these results suggest herds of not more than 15 fertile cycling mares per stallion for one heat cycle of preferably, a maximum of 20 fertile cycling mares per stallion staying in the herd for 6 weeks (two heat cycles) at least.
\end{abstract}

Keywords: $\quad$ sexual-behaviour, fertility, Icelandhorses, heat-cycles, ovulation

\section{Sexualverhalten und Fruchtbarkeit in Islandpferd-Herden}

Während der letzten Jahre wurde von den Pferdezüchtern Islands eine sinkende Fruchtbarkeit in ihren Pferdeherden bemerkt. Um einflussnehmende Faktoren auf die Fruchtbarkeitslage herauszufinden, wurden verschiedene Aspekte in den einzelnen Stuten/Hengstherden untersucht. Von 1996-1998 wurden nahezu 100 Herden mit mehr als 2000 Stuten (9-39 je Herde) mit je 1 Hengst (Alter 2-26 Jahre) pro Gruppe beobachtet und überwacht. Die Untersuchungen wurden wiederholt über 8-9 Wochen durchgeführt, beginnend spätestens mit dem 50. Tag nach Zuführung des Hengstes zur Herde. Die Untersuchungen umfassten wöchentliche Blutserumentnahmen zur Messung des equinen Choriongonadotropin (eCG) mit einen Ezyme linked Immunoabsorbent Assay (ELISA). Die Gesamtträchtigkeitsrate der Herden betrug 76\% wenn der jeweilige Hengst für wenigstens 10 Wochen bei der Herde war und die Stuten belegen konnte.

Zwei weitere Herden wurden intensiver untersucht durch tägliche 24stündige Beobachtung über einen Zeitraum von einem und zwei Zyklusperioden, was durch die geographisch bedingten sommerlichen Lichtverhältnisse in Island möglich wurde. Die Beobachtung selbst wurde von einem im Zentrum der Weide plazierten Campingbus aus durchgeführt. Die Stuten waren auf weite Sicht hin markiert. Einige der Stuten wurden klinisch-gynäkologisch einschliesslich ultrasonographisch untersucht, um den Zeitpunkt des Beginns der Rosse und den Tag der Ovulation zu präzisieren. Herde A bestand aus 23 fertilen Stuten und einem 9 Jahre alten Hengst. Herde B wurde aus 10 fertilen Stuten und einem 3jährigen Hengst zusammengestellt. Die Herden wurden 42 Tage bzw. 28 Tage lang kontinuierlich beobachtet. Die Hengste deckten die Stuten ihrer Herden im Mittel 6,0 bzw. 5,7 mal je Rosse die 4,4 bzw. 4,7 Tage dauerte. Das Befruchtungsergebnis, bewertet nach der Abfohlrate, betrug $87 \%$ bzw. $90 \%$ Abfohlungen, ein Ergebnis, das damit eindeutig über dem Mittelwert (76\%) der Trächtigkeitsrate in der anderen großen, eCG-untersuchten Gruppe lag.

Einer der größeren Einflussfaktoren auf den unterschiedlichen Befruchtungserfolg in den einzelnen untersuchten Herden (36\%-96\%) war das Verhältnis Stutenzahi je Hengst bezogen auf je eine Rosse. Auch das Alter der Hengste und die Zusammensetzung der Stutenherde ist von Bedeutung. Um ein optimales Abfohlergebnis in Islandpferdherden in Weidehaltung zu erzielen, sollte aufgrund der vorliegenden Ergebnisse je Rosse die Anzahl der Stuten pro Hengst nicht größer als 15 betragen oder - vorzugsweise - aus höchstens 20 gesunder und gut rossender Stuten bestehen, die dem Hengst für wenigstens 6 Wochen (= 2 Zyklen) zugeteilt werden.

Schlüsselwörter Sexualverhalten, Fruchtbarkeit, Islandpferde, Rosse, Ovulation

\section{Introduction}

The Icelandhorse is the only breed of horses in Iceland. Presently the total population is approximately 80.000 . The breed has evolved from the horses that the Vikings brought to Iceland in the years 874-940 AC. Since that time a ban on horse import has been in effect in Iceland, to prevent the transmission of diseases from abroad and to protect the sturdy breed that had survived the harsh weather the first few decades in their new home, from breeding with weaker kin. 
The breeding of horses has become of increasing importance for farmers in the last few decades and naturally so has the demand for satisfactory fertility in the stock. During 1985-1995 owners of mares have increasingly stated their concern over slack performance of stallions and mares. We decided to study the breeding process of Icelandhorses in herds to locate the aspects of the process that affected fertility. The following items were investigated:

- The duration of the heat cycle

- The number of mountings during a heat cycle

- Is the mounting close to ovulation, i.e. does the stallion identify the ovulation

- The time needed for the stallion to ensure satisfactory fertility in the herd

- The optimum number of mares in each herd

\section{Materials and methods}

Study 1

During 1996-1997 two herds with stallions were investigated. Herd A comprised an 9 year old stallion and 23 mares age 4-20. The animals were wild and grazing all year around. Herd B comprised a 3 year old stallion with no former experience and 10 tame mares age 3-17 (see table 1). Herd A was observed continuously 24 hours a day for 42 days and herd $B$ for 28 days.

The herds were fenced off for easy observation. A camper was located in the middle of the field and the mares watched continuously from the camper in three shifts. Mares were labelled with large numbers located on both sides of the animal and could be easily identified from a

Tab. 1: Members of the herds

Zusammensetzung der Herden

\begin{tabular}{|lc|c|c|c|c|}
\hline $\begin{array}{l}\text { Herd A } \\
\text { Mares / }\end{array}$ & Age & Number & Foals & Pregnant & Empty \\
\hline Group 1/ & $0-8$ & $15^{\star}$ & 8 & 4 & 2 \\
\hline Group 2/ & $9-16$ & 7 & 4 & 2 & 1 \\
\hline Group 3/ & $17-24$ & 1 & 1 & None & None \\
\hline Stallion & 9 & 1 & & & \\
\hline Total & & 24 & 13 & 6 & 3 \\
\hline
\end{tabular}

*One mare had a miscarriage just prior to starting the observation

\begin{tabular}{|lc|c|c|c|c|}
\hline $\begin{array}{l}\text { Herd B } \\
\text { Mares / }\end{array}$ & Age & Number & Foals & Pregnant & Empty \\
\hline Group 1/ & $0-8$ & 4 & None & None & 4 \\
Group 2/ & $9-16$ & 5 & 1 & None & 4 \\
Group 3/ & $17-24$ & 1 & None & None & 1 \\
Stallion & 3 & 1 & & & \\
\hline Total & & 11 & 1 & None & 9 \\
\hline
\end{tabular}

considerable distance through binoculars. All sexual behaviour was observed. A part of the group underwent ultrasonography per rectum (ALOKA, $5 \mathrm{MHz}$ ) to determine the exact time of ovulation. A portable PC (Psion-Workabout) with Observer 2.0 was used for data. At intervals data was downloaded to a larger computer. To prevent the loss of data, the sexual behaviour was also written on ready made data-forms. All events were logged in real time, and the position of the group was logged every hour.

\section{Study 2}

In the years 1996-1998 close to 100 breeding herds comprising over 2000 mares (from 9 to 39 per herd) with one stallion per herd (age from 2 to 26 years) were monitored repeatedly for $8-9$ weeks, starting at least 50 days after the stallion joined the mares. Monitoring comprised weekly serum sampling and determination of pregnancy by means of measuring equine choriogonadotropin (eCG) levels by enzyme linked immunosorbent assay (ELISA). Each stallion was introduced to a herd of mares in the beginning of June and did not leave until in the beginning of September. The fertility hormone, eCG, starts to appear in the bloodstream 37-41 day after conception (Hoppen, 1994). First samples for eCG assays were taken in late July, when the stallion had been with the mares for 55 days $( \pm 3.5)$. Positive results at that time indicated the number of pregnancies obtained during the first two weeks of the study.

\section{Results}

Study 1

The 3 year old stallion started out by collecting the mares once it was released into the herd. The older stallion had

Tab. 2: Pregnancies (\% of total) during a 9 week period with stallions of different ages in the years 1996 and 1997

Trächtigkeitsraten (\% von gesamt) während eines 9-wöchigen Zeitraums mit Hengsten unterschiedlichen Alters

\begin{tabular}{|l|c|c|c|c|}
\hline Stallions & & Pregnant & $\begin{array}{c}\text { Number of } \\
\text { mares }\end{array}$ & $\begin{array}{c}\text { Mares/ } \\
\text { Stallion }\end{array}$ \\
\hline 2 years & $n=3$ & $74 \%$ & $n=34$ & 11 \\
3 years & $n=7$ & $80 \%$ & $n=138$ & 20 \\
4 years & $n=4$ & $76 \%$ & $n=82$ & 21 \\
5 years & $n=5$ & $78 \%$ & $n=122$ & 24 \\
6 years & $n=6$ & $73 \%$ & $n=155$ & 26 \\
$7-13$ years & $n=20$ & $76 \%$ & $n=520$ & 26 \\
14-25 years & $n=8$ & $69 \%$ & $n=163$ & 20 \\
\hline Total & 53 & & 1214 & 23 \\
\hline Average & & $75 \%$ & & \\
\hline
\end{tabular}


been grazing with the mares all year around. A characteristic behaviour for both stallions was that they collected the mares and kept them in a tight group during the mating season. This behaviour is well known amongst other breeds and has been described by Antonius (1937), Ebhardt (1957), McDonnell (1986). The stallions were constantly moving around the herd while it was grazing and behind the herd while it was moving. When mares attempted to leave the group the stallion stopped them with force and collected them back into the group. When it was herding the mares it lowered the head close to the ground and laid the ears backwards as if it was threatening the mares. The mares were scared by this behaviour and the stallion only needed to show it for the mares to behave. The younger stallion was not as good as the older stallion in herding the mares. Both stallions kept mostly behind the mares while they were moving and grazing. They inspected the area where the mares had been and searched for new dungs or places where the mares had urinated. They sniffed the excrement very carefully, made a flehmen response although not always, and either urinated or defecated on top of the newly deposited dung or urine. It looked like they were driving the heard on in order for them to investigate the area where the mares had been. A stallion can have a relationship with a mare and her excrement for days on while the mare is in heat. Sveinsson (1997) has observed a correlation between herding and the above described behaviour in 4 additional Icelandhorse herds with stallions which he studied in 1995 and 1996.

Both stallion and mares were active during the mating period. A few days prior to copulation the mares (one or more in heat) started to follow the stallion and to present themselves by lifting the tail, winking, and backing towards the nose of the stallion, repeating the behaviour many times during an hour. The mare allowed the stallion to mount and copulate without protest if she was in heat. A mare in heat often stayed close by the stallion and often they were grazing side by side. The stallion then sometimes

Tab. 3: Results of eCG assays for herds with 9-15 mares

Ergebnisse der Messung des equinen Choriongonadotropins für Herden mit 9-15 Stuten

\begin{tabular}{|c|c|c|c|c|c|c|c|c|c|c|c|c|c|}
\hline Stallion & Age & Pregnant & Mares/group & Pregnant, \% & We. $1^{*}$ & We.2 & We.3 & We.4 & We.5 & We. 6 & We.7 & We.8 & We.9 \\
\hline V 37 & 2 & 6 & 9 & 67 & 4 & 1 & 1 & & & & & & \\
\hline N 37 & 5 & 9 & 10 & 90 & 5 & 2 & 1 & & & 1 & & & \\
\hline A 26 & 4 & 10 & 11 & 91 & 4 & & 3 & & 1 & & & 2 & \\
\hline N 56 & 4 & 9 & 11 & 82 & & & & 5 & & 4 & & & \\
\hline F 26 & 2 & 7 & 12 & 58 & 3 & 1 & 2 & 1 & & & & & \\
\hline$\vee 16$ & 18 & 11 & 12 & 92 & 7 & & 2 & 2 & & & & & \\
\hline B 26 & 3 & 11 & 13 & 85 & 2 & & 1 & 2 & 1 & 3 & & 1 & 1 \\
\hline A 17 & 2 & 12 & 13 & 92 & 4 & & 5 & 1 & & 1 & 1 & & \\
\hline A 27 & 3 & 10 & 13 & 77 & 4 & & 4 & & & 1 & 1 & & \\
\hline M 26 & 9 & 11 & 14 & 79 & 6 & 1 & 3 & 1 & & & & & \\
\hline G 27 & 6 & 14 & 15 & 93 & 8 & & 2 & 4 & & & & & \\
\hline Total & & 110 & 133 & 906 & 47 & 5 & 24 & 16 & 2 & 10 & 2 & 3 & 1 \\
\hline Average & 5.3 & 10 & 12 & $82 \%$ & & & & & & & & & \\
\hline \multicolumn{4}{|c|}{ Cumulative pregnancies, mares } & & 47 & 52 & 76 & 92 & 94 & 104 & 106 & 109 & 110 \\
\hline \multicolumn{5}{|c|}{ Cumulative pregnancies (\%) of total pregnant mares } & $43 \%$ & $47 \%$ & $69 \%$ & $84 \%$ & $85 \%$ & $95 \%$ & $96 \%$ & $99 \%$ & $100 \%$ \\
\hline \multicolumn{5}{|c|}{ Cumulative pregnancies (\%) of total mares } & $35 \%$ & $39 \%$ & $57 \%$ & $69 \%$ & $71 \%$ & $78 \%$ & $80 \%$ & $82 \%$ & $83 \%$ \\
\hline \multicolumn{14}{|c|}{ Average pregnancies in first 3 weeks/stallion: $(52 / 11)=5$} \\
\hline \multicolumn{14}{|c|}{ Average pregnancies in first 6 weeks/stallion: $(94 / 11)=9$} \\
\hline \multicolumn{14}{|c|}{ Average pregnancies in 9 weeks/stallion: $(110 / 11)=10$} \\
\hline \multicolumn{14}{|c|}{ Average number of mares/stallion: $(133 / 11)=12$} \\
\hline \multicolumn{14}{|c|}{ Empty mares/stallion: $(133-110) / 11=2$} \\
\hline \multicolumn{14}{|c|}{ Age range of stallions: $2-18$ years } \\
\hline \multicolumn{14}{|c|}{ Average age of stallions: 5,3 years } \\
\hline${ }^{\star}$ Numbe & er of $m$ & ares pregna & ant/week & & & & & & & & & & \\
\hline
\end{tabular}

We $=$ Week 
mounted her without all foreplay and copulated. It could take less than one minute for some cases. Often the stallion rests for a few seconds on the mare after ejaculation. Then they resumed grazing side by side or went each their separate ways. On the other hand, if the mare is not in heat or just about to enter the heat period, she fights back by kicking with the hindlegs towards the stallion. Several times the stallions attempted to mount mares not in heat. They fought back vigorously, the stallion herded them back and forth for up to 20 minutes to wear them out. If they succumbed the stallion mounted them and entered, but if they were stronger he gave up. The stallion kept itself on the perimeter of the herd most of the time. Sometimes he stopped grazing very suddenly, neighed loudly, ran into the group mares and mounted a certain mare. Most often it was a mare in heat and depending on if she was in full heat or not, he mounted and entered quickly and surely. The stallion only showed interest to those mares that were in full heat when many mares were in heat. Of those, the mares that were most active in presenting themselves were the ones that he mounted and entered most often.

Tab. 4: Results of eCG assays for herds with 16-20 mares

Ergebnisse der Messung des equinen Choriongonadotropins für Herden mit 16-20 Stuten

\begin{tabular}{|c|c|c|c|c|c|c|c|c|c|c|c|c|c|}
\hline Stallion & Age & Pregnant & Mares/group & Pregnant,\% & We.1* & We.2 & We. 3 & We.4 & We.5 & We. 6 & We.7 & We. 8 & We.9 \\
\hline$\vee 27$ & 25 & 12 & 16 & 75 & 4 & 3 & 3 & & 1 & & 1 & & \\
\hline N 27 & 10 & 13 & 17 & 76 & 8 & 1 & 1 & 1 & 1 & & 1 & & \\
\hline T 17 & 18 & 7 & 17 & 41 & 2 & 1 & 2 & & 1 & 1 & & & \\
\hline A 16 & 5 & 16 & 18 & 89 & 4 & & 1 & 6 & 3 & & & 2 & \\
\hline L 16 & 11 & 15 & 18 & 83 & 9 & 3 & & 2 & & 1 & & & \\
\hline N 36 & 6 & 10 & 19 & 53 & 5 & & 3 & 1 & 1 & & & & \\
\hline $\mathrm{K} 17$ & 12 & 17 & 19 & 89 & 9 & 3 & & 2 & 2 & 1 & & & \\
\hline L 37 & 3 & 17 & 19 & 89 & 11 & 6 & & & & & & & \\
\hline$\times 17$ & 3 & 19 & 20 & 95 & 7 & 7 & 3 & 1 & 1 & & & & \\
\hline$\vee 26$ & 24 & 13 & 20 & 65 & 11 & & 1 & 1 & & & & & \\
\hline Total & & 139 & 183 & 755 & 70 & 24 & 14 & 14 & 10 & 3 & 2 & 2 & \\
\hline Average & 12 & 14 & 18 & $76 \%$ & & & & & & & & & \\
\hline \multicolumn{4}{|c|}{ Cumulative pregnancies, mares } & & 70 & 94 & 108 & 122 & 132 & 135 & 137 & 139 & \\
\hline \multicolumn{5}{|c|}{ Cumulative pregnancies (\%) of total pregnant mares } & $50 \%$ & $68 \%$ & $78 \%$ & $88 \%$ & $95 \%$ & $97 \%$ & $99 \%$ & $100 \%$ & \\
\hline \multicolumn{5}{|c|}{ Cumulative pregnancies (\%) of total mares } & $38 \%$ & $51 \%$ & $59 \%$ & $67 \%$ & $72 \%$ & $73 \%$ & $75 \%$ & $76 \%$ & \\
\hline \multicolumn{14}{|c|}{ Average pregnancies in first 3 weeks/stallion: $(94 / 10)=9$} \\
\hline \multicolumn{14}{|c|}{ Average pregnancies in first 6 weeks/stallion: $(132 / 10)=13$} \\
\hline \multicolumn{14}{|c|}{ Average pregnancies in 9 weeks/stallion: $(139 / 10)=14$} \\
\hline \multicolumn{14}{|c|}{ Average number of mares/stallion: $(183 / 10)=18$} \\
\hline \multicolumn{14}{|c|}{ Empty mares/stallion: $(183-139) / 10=4$} \\
\hline \multicolumn{14}{|c|}{ Age range of stallions: $3-25$ years } \\
\hline \multicolumn{6}{|c|}{$\begin{array}{l}\text { Average age of stallions: } 12 \text { years } \\
\text { * Number of mares pregnant/week }\end{array}$} & & & & & & & & \\
\hline
\end{tabular}

The mares in herd A were 4.4 days in heat on the average and the mares in herd $B$ were 4.7 days. Individual mares were in heat from 2 to 8 days. A mare was considered starting in heat if she presented herself to the stallion or agreed to copulation. The mare stopped being in heat when the stallion did not want her anymore or if she fought him off. Sometimes the stallion tried to mount mares that were not in heat or just starting in heat, when no mares in heat were available. Also, mares presented themselves to the stallion up to two days after ovulation, but the stallion was usually not interested. The number of days that passed from the time the stallion started to show interest and until the mare was ready was on the average 1.3 days. The mares continued presenting themselves following ovulation on the average for 1.6 days. When these numbers are taken into account the heat cycle was 7.3 days for mares in herd $A$ and 7.6 days for herd $B$ which is similar to what other authors have reported for other breeds (Asa et al., 1979; Day, 1940; McKenzie and Andrews, 1937; Ginther, 1979). On the basis of the findings the heat cycle can be divided into three events: pre-heat; full-heat and post-heat cycle. Since the

We $=$ Week 
transition from one event to the next was often difficult to pinpoint the heat cycle used in this study was from the time that both parties showed interest and until one party lost interest. The stallions copulated with mares at all times during day or night. A successful copulation was noted when the stallion mounted, entered the mare, flagged his tail and jumped off with a limp penis. The stallion in herd $A$ had 6 copulations with each mare on the average or from 1-11 with individual mares. Unsuccessful attempts were 4 on the average and between 2-9 for each mare. The stallion in herd $B$ had 5.7 copulations and 2.4 unsuccessful attempts. Stallion A was more attentive to the mares than stallion $B$ because he had only one mare to attend at any one time, whereas for stallion B up to 7 mares could be in heat at one time. This can also be shown from the length of time the stallions showed mares in heat interest. For stallion $A$ the average time was 55 hours with a range from 3682 hours and for stallion $B$ the average time was 58 hours with a range from 12152 hours. Although the average time was similar between the horses, the range was larger for $\mathrm{B}$. When many mares were in heat at the same time the stallion had less time for each of them and some of them got left out for a while (explaining the upper limit). The stallions used only 2.2-2.4 days on the average to copulate with the mares, even though the mares were in heat for 4.4-4.7 days, which indicated that the stallions maybe identified their time of ovulation. Another indication of the stallions sense of timing was that they lost interest in the mare very shortly following ovulation.

Tab. 5: Results of eCG assays for herds with 21-25 mares

Ergebnisse der Messung des equinen Choriongonadotropins für Herden mit 21-25 Stuten

\begin{tabular}{|c|c|c|c|c|c|c|c|c|c|c|c|c|c|}
\hline Stallion & Age & Pregnant & Mares/group & Pregnant, \% & We.1* & We.2 & We.3 & We.4 & We. 5 & We. 6 & We.7 & We.8 & We.9 \\
\hline L36 & 9 & 20 & 21 & 95 & 12 & 2 & 5 & & & & & 1 & \\
\hline N 26 & 9 & 16 & 21 & 76 & 8 & 3 & 3 & & & 2 & & & \\
\hline V 36 & 3 & 18 & 22 & 82 & 11 & 1 & 2 & 1 & 1 & 1 & & 1 & \\
\hline L 16 & 14 & 8 & 22 & 36 & 2 & 1 & 1 & & 1 & 2 & 1 & & \\
\hline T 26 & 16 & 18 & 22 & 82 & 8 & 4 & 4 & 2 & & & & & \\
\hline B 27 & 6 & 16 & 23 & 70 & 5 & & 1 & & 4 & 5 & & 1 & \\
\hline T 16 & 8 & 13 & 23 & 57 & 9 & 1 & 2 & 1 & & & & & \\
\hline N 16 & 9 & 19 & 23 & 83 & 12 & 1 & 3 & & 2 & & & & 1 \\
\hline$\times 16$ & 11 & 17 & 23 & 74 & 8 & 1 & & 4 & 4 & & & & \\
\hline G 17 & 4 & 16 & 24 & 67 & 12 & & & & 1 & & 2 & 1 & \\
\hline $\mathrm{K} 26$ & 5 & 19 & 24 & 79 & 5 & 5 & 5 & 1 & 2 & 1 & & & \\
\hline B 16 & 6 & 21 & 24 & 88 & 1 & & 2 & 3 & & 11 & 2 & 2 & \\
\hline B 17 & 7 & 23 & 24 & 96 & 15 & 1 & 3 & 2 & 2 & & & & \\
\hline N 17 & 10 & 19 & 24 & 79 & 13 & 1 & 3 & & & 1 & & 1 & \\
\hline K 27 & 3 & 17 & 25 & 68 & 9 & 3 & 2 & 2 & 1 & & & & \\
\hline Total & & 260 & 345 & 1132 & 130 & 24 & 36 & 16 & 18 & 23 & 5 & 7 & 1 \\
\hline Average & 8 & 17 & 23 & $75 \%$ & & & & & & & & & \\
\hline \multicolumn{4}{|c|}{ Cumulative pregnancies, mares } & & 130 & 154 & 190 & 206 & 224 & 247 & 252 & 259 & 260 \\
\hline \multicolumn{5}{|c|}{ Cumulative pregnancies $(\%)$ of total pregnant mares } & $50 \%$ & $59 \%$ & $70 \%$ & $79 \%$ & $86 \%$ & $95 \%$ & $97 \%$ & $99 \%$ & $100 \%$ \\
\hline \multicolumn{5}{|c|}{ Cumulative pregnancies (\%) of total mares } & $38 \%$ & $45 \%$ & $55 \%$ & $60 \%$ & $65 \%$ & $72 \%$ & $73 \%$ & $75 \%$ & $75 \%$ \\
\hline \multicolumn{14}{|c|}{ Average pregnancies in first 3 weeks/stallion: $(154 / 15)=10$} \\
\hline \multicolumn{14}{|c|}{ Average pregnancies in first 6 weeks/stallion: $(224 / 15)=15$} \\
\hline \multicolumn{14}{|c|}{ Average pregnancies in 9 weeks/stallion: $(260 / 15)=17$} \\
\hline $\begin{array}{l}\text { Average } r \\
\text { Empty me } \\
\text { Age rang } \\
\text { Average } \\
\text { * Number }\end{array}$ & $\begin{array}{l}\text { numb } \\
\text { ares/s } \\
\text { e of } s \\
\text { age o } \\
\text { r of } m\end{array}$ & $\begin{array}{l}\text { er of mares/ } \\
\text { tallion: (345 } \\
\text { tallions: } 3-1 \\
\text { f stallions: } 8 \\
\text { ares pregna }\end{array}$ & $\begin{array}{l}\text { stallion: (345/1 } \\
-260) / 15=6 \\
6 \text { years } \\
\text { years } \\
\text { nt/week }\end{array}$ & 5) $=23$ & & & & & & & & & \\
\hline
\end{tabular}

We $=$ Week 


\section{Study 2}

In 1996 and 1997 the pregnancy hormone eCG was assayed in mares from 53 herds with one stallion in each herd. The total number of mares was 1214. Blood samples from each mare were taken once every week for 8-9 weeks onwards starting 55 days ( \pm 3.5 days) after each stallion was first introduced to his herd. The first week of sampling was termed week 1 . The number of positive results for the eCG hormone in week 1 indicated the number of mares that became pregnant in the first two weeks with the stallion.
The results from week 2 indicated successful pregnancies in the third week with the stallion and so on. The results for the 9 week period are shown in table 2 .

Pregnant mares were $75 \%$ of total mares during the years 1996 and 1997 (table 2) and in the following year (1998/ data not shown) the percentage of pregnant mares was $76 \%$ from a large sample of wild herds (> 1000 mares). As can be seen from the table, the fertility of the stallions was not significantly dependent on age until in the age group $14-25$ years where a decrease from the average was seen (69\% vs $75 \%)$.

Tab. 6: Results of eCG assays for herds with 26-39 mares

Ergebnisse der Messung des equinen Choriongonadotropins für Herden mit 26-39 Stuten

\begin{tabular}{|c|c|c|c|c|c|c|c|c|c|c|c|c|c|}
\hline Stallion & Age & Pregnant & Mares/group & Pregnant,\% & We.1* & We.2 & We.3 & We.4 & We.5 & We.6 & We.7 & We.8 & We.9 \\
\hline$\vee 17$ & 3 & 19 & 26 & 73 & 5 & 3 & 4 & 1 & & 2 & 4 & & \\
\hline N 47 & 7 & 15 & 27 & 56 & 10 & & 1 & & 3 & & & 1 & \\
\hline F 16 & 16 & 22 & 27 & 81 & 8 & 3 & 5 & 1 & 2 & 3 & & & \\
\hline $\mathrm{R} 17$ & 18 & 21 & 27 & 78 & 9 & & 1 & 5 & 1 & 4 & & 1 & \\
\hline F 47 & 8 & 18 & 29 & 62 & 7 & 3 & & 5 & 1 & 2 & & & \\
\hline R 27 & 13 & 24 & 29 & 83 & 13 & 2 & 5 & 1 & 1 & & 1 & 1 & \\
\hline G 16 & 5 & 26 & 32 & 81 & 14 & 1 & 2 & 4 & & 3 & 2 & & \\
\hline$\llcorner 17$ & 10 & 27 & 32 & 84 & 8 & 8 & 3 & 3 & 2 & 1 & & 2 & \\
\hline L27 & 11 & 24 & 32 & 75 & 9 & 6 & 3 & 1 & 3 & 1 & & & 1 \\
\hline K 37 & 8 & 26 & 33 & 79 & 9 & 4 & 2 & 4 & 4 & 3 & & & \\
\hline E 17 & 6 & 28 & 35 & 80 & 15 & 5 & 5 & & 2 & 1 & & & \\
\hline K 36 & 4 & 27 & 36 & 75 & 14 & 3 & 3 & 3 & 4 & & & & \\
\hline P 16 & 8 & 20 & 37 & 54 & 12 & 3 & 1 & 2 & 2 & & & & \\
\hline M 16 & 11 & 22 & 37 & 59 & 11 & 1 & 1 & 6 & & 1 & & 2 & \\
\hline P 17 & 9 & 28 & 37 & 76 & 15 & 1 & 4 & 1 & 2 & & 4 & 1 & \\
\hline$F 16$ & 5 & 25 & 38 & 66 & 14 & & 6 & 2 & & 1 & 1 & 1 & \\
\hline N 46 & 6 & 24 & 39 & 62 & 7 & 4 & 2 & 2 & 1 & 2 & 3 & & 3 \\
\hline Total & & 396 & 553 & 1224 & 180 & 47 & 48 & 41 & 28 & 24 & 15 & 9 & 4 \\
\hline Average & 9 & 23 & 33 & $72 \%$ & & & & & & & & & \\
\hline \multicolumn{4}{|c|}{ Cumulative pregnancies, mares } & & 180 & 227 & 275 & 316 & 344 & 368 & 383 & 392 & 396 \\
\hline \multicolumn{5}{|c|}{ Cumulative pregnancies (\%) of total pregnant mares } & $45 \%$ & $57 \%$ & $69 \%$ & $80 \%$ & $87 \%$ & $93 \%$ & $97 \%$ & $99 \%$ & $100 \%$ \\
\hline \multicolumn{5}{|c|}{ Cumulative pregnancies (\%) of total mares } & $33 \%$ & $41 \%$ & $50 \%$ & $57 \%$ & $62 \%$ & $67 \%$ & $69 \%$ & $71 \%$ & $72 \%$ \\
\hline \multicolumn{14}{|c|}{ Average pregnancies in first 3 weeks/stallion: $(227 / 17)=13$} \\
\hline \multicolumn{14}{|c|}{ Average pregnancies in first 6 weeks/stallion: $(344 / 17)=20$} \\
\hline \multicolumn{14}{|c|}{ Average pregnancies in 9 weeks/stallion: $(396 / 17)=23$} \\
\hline \multicolumn{14}{|c|}{ Average number of mares/stallion: $(553 / 17)=33$} \\
\hline \multicolumn{14}{|c|}{ Empty mares/stallion: $(553-396) / 17=9$} \\
\hline \multicolumn{14}{|c|}{ Age range of stallions: $3-18$ years } \\
\hline \multicolumn{14}{|c|}{ Average age of stallions: 9 years } \\
\hline \multicolumn{6}{|c|}{ * Number of mares pregnant/week } & & & & & & & & \\
\hline
\end{tabular}

We $=$ Week 
The average age of stallions in table 3 was the lowest (5.3) of all sets studied, they however had the highest ratio of pregnant mares (82\%). The reason was most likely that they had relatively few mares per herd, or 12 on the average. The gestation was late, most likely, due to inexperience of the young stallions.

In the set of mares described in table 4 , the percentage of pregnant

mares was satisfactory (76\%) in week 5 (after 6 weeks with the stallion). The average age of stallions was 12 years and average number of mares with the stallion was 18. The average number of mares with the stallion was 23 in the set described in table 5. The satisfactory percentage of pregnant mares $(75 \%)$ was attained in week 6 one week later than for the set in table 4 were the average number of mares with stallion was 18 . The pregnancy rate between the two sets was similar but the stallions appeared to need slightly more time to serve the mares. When the number of mares exceeded 26 per stallion the fertility decreased. As the number of mares per stallion increased the total number of pregnancies during the 10 weeks with stallion increased but so did also the number of empty mares. The average pregnancies/stallion was 23 when the total number of mares was 33 (table 6). In week 5 the percentage of pregnant mares was $62 \%$ and $67 \%$ in week 6 . The high number of mares thus placed a limit on the rate of making mares pregnant as well as the overall success of the stallion $(71 \%)$.

\section{Discussion}

The sexual behaviour of the Icelandhorse was not different from what authors have described for other breeds (Asa et al. 1979; Asa, 1986, Bristol, 1982; McDonnell, 1992; Tyler, 1972). Both the stallion and the mare took an active part in the sexual activity. It appeared that the stallion herded the mares in a tight group, maybe in order to be able to determine more easily which mares were in heat and when they were getting close to ovulation. By inspecting their excrement they were able to obtain the information possibly through pheromones. The fact that they spent only 2.2-2.4 days on the average for copulations even though the mares were in heat for 4.4-4.7 days, substantiated this idea. Asa (1986) claims that when the ma$r e$ is winking it may be informing the stallion of her situation through pheromones. Other authors have explained this differently (Feist and McCullough, 1976; Klingel, 1972; Pellegrini, 1971; Schloeth, 1958). The stallions copulated with mares at any time day or night and more often with the ones that were active in presenting themselves. Some mares were left out and had fewer servings if many mares were in heat at the same time, increasing the possibility of non pregnancy forthose mares.

The results for the large sample of wild herds indicated that the age of stallions was not a significant issue in fertility management as it did not affect their fertility from 3 to 14 years of age and only slightly thereafter. Even a very old stallion (25 years) had $75 \%$ pregnant mares from a herd of 16 mares and the 2 year olds were reasonably successful (74\%) with small herds. The size of the herd was a larger issue. Stallions with an excess of mares made 13 mares pregnant on the average during the first 3 weeks and 20 during the first 6 weeks of contact. The highest overall pregnancies (82\%) were obtained for stallions that had the fewest number of mares (12) in the herd. Satisfactory results (76\%) were also obtained with herds of 16-20 mares. When the stallion had an excess of mares, the rate at which he made the mares pregnant decreased when compared to the average of all herds. This observation was in accordance with the results from the behaviour study, where it was observed that the stallion had less time for each mare and

left

some of them out for a while, if many mares were in heat at the same time.

From the study we can conclude that the optimum number of mares with a stallion for 3-4 weeks is not more than 13-15 if a high rate of pregnancy is to be obtained. For even better results the mares should stay with the stallion for two heat periods ( 6 weeks) but not exceeding 20 mares/herd.

\section{Literature}

Antonius, O. (1937): Über Herdenbildung und Paarungseigentümlichkeiten der Einhufer. Z. Tierpsychol. 1, 259-267

Asa, Cheryl S., Goldfoot, D.A., and Ginther, O. J. (1979): Sociosexual Behaviour and the Ovulatory Cycel of Ponies (Equus caballus) in Harem Groups, Hormones and Behaviour, 13, 49-65

Asa, Cheryl. S. (1986): Sexual behaviour of Mares. Veterinary Clinics of North America: Equine Practice, Vol. 2, No. 3, 519-534

Bristol, F. (1982): Breeding behaviour of a stallion at pasture with 20 mares in synchronised oestrus, J. Reprod. Fert. , Suppl. 32, 71-77

Day, F.T. (1940): Clinical and experimental observations on reproduction in the mare. J. Agr. Sci. 30, 244-261

Ebhardt, H. (1957): Drei unterschiedliche Verhaltensweisen von is landpferden in norddeutschen Freigehegen. Säugetierkundl. Mitt. Stuttgart, 5, 113-117

Feist, J.D. and MCCullough, D.R. (1976): Behaviour Patterns and Communication in Feral Horses. Z. Tierpsychol., 41, 337-371

Ginther, O. J. (1979): Reproductive Biology of the Mare. McNaughton and Gun, Ann Arbour, Mich.

Hoppen, H.O. (1994): The equine placenta and equine chorionic go nadotrophin - an overview. Exp. Clin. Endocrinol., 102, 235-243

Klingel, H. (1972): Das Verhalten der Pferde (Equidae). Handbuch Zoolog. 8, 1-68

McDonnell, Sue M. (1986): Reproductive Behaviour of the Stallion, Veterinary Clinics of North America: Equine Practice, Volume 2, 535-555

McDonnell, Sue M. (1992): Normal and abnormal sexual behaviour. Veterinary Clinics of North America: Equine Practice, Volume 8, 71-89

McKenzie, F.F. and Andrews, F.N. (1937): Estrous and ovulation in the mare. Proc. Amer. Soc. Anim. Prod. 30, 64-70

Pellegrini, S. (1971): Home range, territoriality and movement patterns of wild horses in the Wassuk Range of western Nevada. Master's 
thesis, University of Nevada, Reno

Schloeth, R. (1958): Das Scharren beim Rind und Pferd. Z. Säugetierk. 23, 139-148

Sveinsson, H.S. (1997): Atferli stóddhesta, Búnadardeildin á Hvanneyri, apríl 1997, 1-44

Tyler, Stephanie J. (1972): The Behaviour and Social Organisation of the New Forest Ponies. Animal Behaviour Monographs, 5, 175-188

\section{Acknowledgements}

We would like to thank Prof. em. Dr. Dr. h. c. mult. H. Merkt, Institut für Reproduktionsmedizin and Prof. Dr. med. vet. E. Klug, Klinik für Pferde der Tierärztlichen Hochschule Hannover, Germany, for aiding us in the design of this project. Also, thanks are due to Heinz Egon Schmeil, Hannover, Holmfridur Einarsdottir and Olafur Sigurdsson at ISTEKA for their valuable input. The study was supported in part by a grant to BS from the Icelandic Research Council (RANNIS) and also in part by a NATO Science Grant 1997-1998 also to BS.
Björn Steinbjörnsson, DVM

Animal hospital Vididalur

Clinic for farm and companion animals

IS-110 Reykjavik

Iceland

Phone: +354 - $5667770 ;+3548924434$

Fax: $+354-5666679$

e-mail: bstein1202@aol.com

\section{Hördur Kristjánsson, Ph.D}

Isteka-Icelandic Pharmaceuticals Ltd

Grensasvegi 8

IS-108 Reykjavik

Iceland

Phone: $+354-5814138$

Fax: $+354-5814108$

e-mail: isteka@vortex.is

\section{0 years $A O$ Vet}

Jubilee course for large and small animals

New concepts in fracture healing

\section{December $5-10,1999$ \\ Davos}

\section{Scientific lectures and practical exercise}

New aspects of bone healing

Balancedosteosynthesis

Multifragment fracture of the proximal phalanx

Arthrodesis of the proximal interphalangeal joint

External skeletal fixation device

Corrective osteotomies

Arthrodesis of the metacarpophalangeal joint

Diagnostic imaging

Preoperative planning

Treatment planning of unknown fracture

Arthroscopy guided osteosynthesis of condylar,

carpal and mid-sesamoid fractures

CHF 1.600

Information and registration

AO Course-Secretariat

Clavadelerstraße, $\mathrm{CH} 7270$ Davos Platz

Tel 0041 814142720 - Fax00418141422 84,Email courses@ao-asif.ch 